Jarosław Piątek ${ }^{1}$

\title{
POLES IN GREAT BRITAIN AFTER 2004. AN ATTEMPT AT ANALYSIS OF SELECTED SECURITY ASPECTS
}

Keywords: Security, migration, Great Britain, public security, public space, monitoring

\begin{abstract}
The multitude of defining the concept of security is related to the fact that representatives of various fields of science describe and perceive this phenomenon from the point of view of terminology, own knowledge, as well as from the scope of their discipline. For many security is a belief that you are out of the reach of any threat. Based on the Copenhagen school theory, the essence of the objective and subjective understanding of security was emphasized. Against this background, the movement of people was analyzed as a security issue. Poles living in Great Britain are more often in contact with this issue than in their country of origin. The scale of threats is extremely different. For Poles migrating to the UK, the most dangerous threats appear to be in the social sphere. The aim of the article is to analyze the phenomenon of Polish migration to Great Britain after 2004. Additionally, the process of describing security and its transition from the sphere of theory to practice was attempted. Although in the open public space, on city streets, parks and squares, there are personal threats related to crimes, as well as to social threats - attacks and assaults caused by frustrated and aggressive groups or individuals, Poles feel safe. Despite knowing about terrorism or manifestations of social or cultural phobias, Poles migrate to Great Britain. In addition, the article attempts to prove that the technological extension of public space leads to a sense of greater security.
\end{abstract}

1 Jarosław J. Piątek, University of Szczecin, Faculty of Humanities, Institute of Political Science and European Studies, jarekpiatek@wp.pl. 


\section{INTRODUCTION}

Migration affects many security spheres, although due to the dynamics of its perception, it is difficult to make unambiguous interpretations. It is relatively easy to present them through their impact on the international security dimension. We can perceive both the positive and negative impact of migration on international relations. Positives include the role it plays for the development of international cooperation. However, population movements can also give rise to serious and difficult problems to solve. They can be both an indirect as well as direct threat to many aspects of security in individual countries, and even entire regions.

The migration of Poles to Great Britain is not a threat due to interstate relations. It has not become the subject of intense diplomatic tensions on intergovernmental character. The overriding objective of migration within the internal borders of the European Union is to increase the global competitiveness of goods and services produced within Member States. This process is to lead to better living conditions for the inhabitants of the European Union. The accentuation of national interests on the territory of the EU has been reflected in bilateral relations between member states, including between Poland and the United Kingdom. At the same time, the migration problem is only one of the factors that affects the level and intensity of Polish-British cooperation. This does not allow for an unambiguous assessment of migration as part of the relations between these countries. At this point, however, it should be noted that the British position in this respect has evolved from openness in the name of "unity" and "solidarity" of the EU to the display of extremely different attitudes. Such a position cannot be surprising. Apart from many advantages of employee migration, their side effects are also noticeable. Poles in Great Britain often cause inflammatory situations that may be the cause of conflicts of an internal nature. Their migration is often a problem of both economic and social nature. Poles migrating to Great Britain after 2004 questioned the labor migration of a short-term nature (usually of several years) accepted in the framework of the countries of the so-called "old Union" connected with permanent (long-term) change of the place of residence. As a consequence, it began to affect the policy 
of the United Kingdom. Seeking its most "effective" aspects, the issue of security was also raised.

\section{POPULATION MOVEMENTS AS A SECURITY ISSUE}

The intensification of interstate population movements can be explained by several factors. First, in view of the growth of the state's control activities, all manifestations of migration are carefully noted by the administrative apparatus of at least two countries. Secondly, the global population continues to grow rapidly. Thirdly, globalization brought a revolution in the circulation of information and transport, which made today people aware of the deep differences in living conditions between individual regions of the world and the opportunities that open to them somewhere else, and at the same time facilitated relocation (Kuźniar, 2005, pp.174-175). Simultaneously, the changes taking place in the world and the occurrence of sharp conflicts induce the population to migrate in the escape of threats or pursuit of prosperity.

Over the past few decades, many events in different countries have increased interest in new aspects of migration. These events include the collapse of the GDR, preceded by the exodus of Germans from the East through Hungary and Austria to the West, migrations in the Balkans, as well as political coups and political destabilization of Afghanistan, Syria, Libya, ethnic cleansing caused by ISIS. The tragic events of September 11, 2001 emphatically reminded us of the role that population movements can play in the sphere of security. When it came to the conclusion that all assailants were foreigners staying in the US temporarily or illegally, the American authorities decided to subordinate the functioning of their immigration services to the objectives of national security; regulations of immigration policy and its procedures were included in the then-adopted US Patriot Act, and from 2015 replaced by the Freedom Act. The law gave the National Security Agency (NSA) the basis for conducting a mass-scale collection program of the so-called metadata about American telephone conversations, which was disclosed by the former CIA employee, Edward Snowden (Uniting and Strengthening 
America ...). With time, when the global goals, scope of operations and the scale of Al-Qaeda organization were better understood, new Western countries took new precautions in the immigration policy, and their need was confirmed by further attacks - in Madrid (March 11,2004 ) and in the London subway (July 21, 2005). Both of these events are symbolic Rubicon. All the assassins were emigrants. It is not surprising that after these events in many countries there is still a broad consensus to the necessity of an open linking of state immigration policy with security policy and control of population movements and management through the prism of security interests. As a consequence, the view prevails that migration can be a threat to people and governments both in the countries of origin of migrants and their host countries, as well as to relations between these two countries (Scheffer, 2010). Greater attention was paid to the issue of security generated by migration between states. It is sometimes a factor in the internationalization of civil wars and the spread of ethnic and folk riots from state to state. It may itself be the source of conflicts, including even regular wars between states (Setki islamistów...). It also happens that migration favors the development of terrorism (Mochnaczewski, Bolesta, 2007, pp. 204-205) and becomes the cause of economic hardships or exacerbates competition for goods that the state does not have in abundance - be it jobs or social housing. It can finally weaken the power structures and institutions existing in the migrant countries, as well as cultural identity and social cohesion.

\section{MIGRATION OF POLES TO GREAT BRITAIN AFTER 2004 AND SUBJECTIVITY AND SAFETY UNDERSTANDING}

The evolution and revision of the security concept, which now also includes threats that were previously overlooked, are the reasons for a new approach to the problem of migration, and in this context also the relationship between migrants and security problems. The contemporary civilization development of the society and the develop- 
ment of technology has meant that the term "security" includes two sectors - on a macro scale - states, continents or the whole world, and also on a micro scale - covering the security of local communities (counties, district - cities, municipalities). Security has become the dominant need, especially at the local level. It results from a number of dependencies, but the most important one is due to the fact that people seek security in the nearest environment. They are not afraid of war, and ensuring security is increasingly felt as a necessity of security at home or in the immediate area. That is why the sphere of the immediate environment of each of us becomes crucial for the security issue. Increasingly, we are dealing with the breakdown of the communities, which consequently also causes the disintegration of space developed these communities (Castells, 2009).

As a consequence of these processes, the public space changes, which refers to global, state, local and personal matters, creating or limiting the opportunities for each of these dimensions (Urban, 2009, p. 11). As of the end of 2015, there were a record number of Poles in the United Kingdom - 916 thousand. In comparison to 2014, this number increased by 63 thousand. Among Poles living in Great Britain, nearly 12 percent (108 thousand) was born in exile. In comparison with 2003 - just before Poland's accession to the European Union - the population of Poles in the United Kingdom increased more than 20 times. Data published showed that from June 2015 to June 2016 as many as 105,000 Poles obtained a social security number (NINo) entitling them to work legally in the United Kingdom. Poles alongside the Indians are the largest national population (28\%) (Poles are biggest non ...). In individual kingdoms, the percentage is also significant. Poles are the biggest national minority in Scotland (46\%) and in Wales (35\%). In Northern Ireland they are on the second place after the Irish (27\%).

The scope and nature of integration of migrant communities and its impact on societal security was analyzed first by Ole Waever (1995, pp. 389-431). The subject of his research was the Muslim communities of Great Britain, France and Denmark in the context of the "war on terrorism". Poles cannot be associated in any way with the global 
war on terrorism. However, the number of Poles staying in the UK cannot be noticed for many other reasons.

Obviously, migrations can bring economic benefits - both to the migrants and to the states - to the state that the migrants leave and to the one he migrates to (Zamojski, 2006, p. 97). The presence of Poles in the UK has far-reaching social consequences. The influx of Poles gives the British society even more multicultural character and is a potentially dangerous factor for the image and power of the state. The state remains the basic form of social organization in the world, which assumes that each country has a self-reproducing cultural and social system based on its territory (Bankowicz, 1999, p. 9; Jastrzębski, 1999, pp.157-158, Wojtaszczyk, 2000, pp. 16-22). The migration of Poles to the United Kingdom is a clear challenge for traditional concepts of nationality and citizenship, as well as rights and obligations of citizens towards the state and the state towards citizens (Orłowska, 2013, pp. 215-216).

For many, Poles can become a threat to social cohesion and stability when migrant communities seem to be an economic burden for the general public. The feeling that immigrants are living with social benefits, and the local housing, education, health and transport infrastructure is under the weight of their numbers and needs, can cause resentment and hostility (Kolejny rasistowski incident...). It is often assumed that migrants are criminals or that in the districts they occupy they spread specifically understood interpersonal relations. The problem of social welfare costs for Poles is becoming one of the main political topics (Zuchowicz). On the wave of social tensions around these phenomena, the extreme political right has revived. The activities of the United Kingdom Independence Party (UKIP) are a manifestation of the internal political forces' influence, prompting the government to stiffen its position on the Poles (Bielecki, 2016a). In the political debate, it is argued that the social benefits model in Great Britain ceases to function efficiently. Supporters of party leaders argue that British taxes are earmarked for helping Poles to arrange their lives, and they are lacking for native people in need.

Poles more and more meet hostile behavior, and in some places they come to be perceived as a threat to culture and lifestyle. Some people think that the influx of Poles to Ulster can cause serious damage to such an 
unstable region and endanger the rather fragile cohesion and social stability of this place (Poland flags burned ...). There is a growing number of attacks on Poles throughout Northern Ireland, in particular in Belfast. In 2013, 307 racist attacks were recorded, in the previous year almost 480, almost a hundred of which were incidents against the Polish community in this city. According to the police, paramilitary militants of loyalists are behind most of the attacks. The inevitable consequence of searching for better living conditions for Poles coming to Great Britain is certainly the emergence of a community of national minorities. It seems that some Poles will inevitably gain the status of citizens in their new place, creating in their society a cultural and linguistic minority, and often a religious minority.

The phenomenon of a large influx of Poles obviously has a significant impact on the security of the state - both in the traditional sense of state freedom from the threat of violence and conflicts, and in the expanded sense of the internal cohesion of the state, social stability and economic well-being - as well as relations between countries in which these minorities arise and those from which they come. Some media often promote the view that Poles are responsible for the increase in crime in the United Kingdom. Poles are the largest group among post-accession immigrants, so they are the most talked about and written about. The attacks of British newspaper boulevards on Poles are often dictated by jealousy towards Polish entrepreneurship and competition. The Pole has become a natural symbol of the wave of immigrants not only because of the number but also the creation of many stigmatizing simplifications. In the first few weeks after the referendum, diplomatic missions in Great Britain recorded 31 serious incidents of physical aggression against Poles. For comparison, the Spaniards, despite the growing wave of immigrants arriving in Great Britain, did not report any. The Embassy of Finland has documented the case when a Finnish woman in London was attacked by hooligans shouting "Go home Poles" (Bielecki, 2016b).

Discussions in the context of tensions in the sphere of security have their background resulting from the description of the potential or actual activity of Polish criminal groups in the UK. Often the slogan "crime among immigrants" turns out to be a great opportunity to mention the Poles (Daily Express ...). Reality turns out to be quite different. The vast 
majority of Poles work hard to support their families, local politics are not interested in the Poles, they focus on their duties, hence the attacks on Poles are incomprehensible. The debate on these problems of Poles, important for their future state of social stability in Great Britain, would certainly be incomplete without considering these factors.

Poles living in the United Kingdom perceive that often the norms of law do not coincide with their implementation. The security of Poles living in the United Kingdom should be ensured not only by generally accepted and used customs and norms of social coexistence, but also the ability to accept. Often, the media showed a 24-year-old resident of Boston and a mother of 2 children, who said that "(...) she and her children must wait for a 3-4 week to get to the doctor." The woman blamed the mass influx of foreigners for this situation by, and consequently according to her opinion "(...) people cannot get a job and arrange a normal appointment with a doctor" (Poland flags burned ...). For the state of certainty of the functioning of Poles, it becomes important to realize that security is not a lack of threats, but an acceptable, low level of risk of their occurrence (Kwiatkowski, Kwiatkowska-Drożdż, 2005, p.22). Based on these assessments, we now have to understand public space as a system of open, generally accessible places that belong to everyone.

Expanding the scope of the security of Poles in Great Britain has led to the emergence of many areas that can be analyzed independently of each other, even though they are interrelated. Certainly, maintaining security is one of the oldest, if not the oldest, public tasks strictly related to the basic function of public authority (Gierszewski, 2013, p. 19).

It is worth noting that public security means all manifestations of the absence of any dangers in the life of a certain community of people. In Great Britain, as well as in other EU countries, it includes communication security, road, rail and water security, as well as no threats related to disasters, natural disasters, epidemics, and finally no threats caused by criminals, directed against life, health of an individual or against property (Misiuk, 2011, p.17).

Poles residing in Great Britain have the right to treat public order interchangeably with security treated as an element of internal stabilization of the state, region, local communities or individual. 


\section{THE USE OF NEW TECHNOLOGIES FOR ENSURING PUBLIC SECURITY}

The idea of individual security is a significant challenge for the traditional understanding of democratization and the development of civil society. Different social, political and economic contexts clearly differentiate the perception of individual security.

Modern threats have significantly changed the view of the issues of the individual security in public space, especially in relation to large metropolises and global cities. The presence of police forces was significantly increased, and the most important buildings were surrounded by barriers and "fortifications". The sense of danger increased among the residents. Known threats in public space, common crime and social threats (riots) have been joined by a new threat on a global scale - terrorism.

Poles living in Great Britain face them in contrast to the environment of their country of origin. The scale of threats is extremely different. In Poland, the sense of threat to the individual is relatively small. Currently $59 \%$ of respondents believe that there is a real threat of terrorism, so the same as in December 2015 (Zagrożenie terroryzmem..., p.1). The protection and security of the individual in the public space have significantly relativized. The potential target of a terrorist attack are not only symbolic buildings, but also all places of large population centers: squares and markets, stadiums, transport infrastructure objects: railway stations and metro lines. The big metropolises had to adapt their solutions regarding the security of public space first. Proposed or applied measures to protect the public space arouse many doubts and sometimes even raise objections - in 2008, in the United Kingdom, the state anti-terrorist service, in cooperation with the British Architects Association and the Royal Association of Fine Arts, organized a competition aimed at designing the security of a fictional city square that resembled Trafalgar Square with its dimensions. In the competition a scenario of a bomb attack was presented, in which 500 people are killed and 1500 injured. The participants' task was to prepare a project of appropriate anti-terrorist security measures. The competition met with numerous protests and a boycott organized by students and lecturers of architectural schools, who accused the organizers of 
"propaganda of paranoia", restricting civil liberties and "assassination of free and open society".

In 2005, the Glasgow authorities decided to create a similar system. In November 2008, a monitoring system covering the southern part of the city was launched. Its "view" covers an area of almost 5 square kilometers. The beginning was modest - 156 cameras and 30 mobile license plate readers. However, by the end of 2015, more than three thousand cameras could track the cars and passers-by. It was also decided that the monitoring system will operate in real time, which means that the images from the cameras is directly viewed in the command center. How to analyze images from the back of cameras? How to get information about a potential terrorist in the multitude of data? This exceeds the perception of up to several hundred supervising people. The problem was solved by introducing intelligent software enabling image analysis.

The streets and squares of London City were controlled and monitored by one of the largest and most advanced anti-terrorism security and video surveillance systems, the so-called "Ring of Steel", before the announcement of the global war on terror. The Ring of Steel was launched in July 1993, following a wave of bomb attacks by the Irish IRA Revolutionary Army. The cordon of security around the City was less prominent than its prototype - the 1972 ring of steel of fortifications around the central Belfast district. London streets were divided by steel pillars, and access roads to checkpoints were marked with plastic bollards. With time, this system was called - the Ring of Plastic but the presence of security measures and police control was still widely felt. Many of the drivers entering the city center did not know the nature of the introduced safeguards, because they did not publicly display their anti-terrorist function. The introduced changes have been translated as measures aimed at limiting vehicular traffic in the center, used to improve traffic and protection. Officially, the anti-terrorist regulation and security system was called the Experimental Traffic Scheme. Over time, the scope of the protected area has increased, now it is over $75 \%$ of the City area. Territorial protection was strengthened by the surveillance of television cameras - both state and private operators. Police forces initiated an action called "Camera Watch", encouraging local entrepreneurs and building owners to install 
CCTV in a coordinated manner, so that video surveillance also applies to the city and streets in the vicinity of guarded private properties. The most advanced camera system was installed in the places of the controlled entrance to the City. Since February 1997, a digital camera system has been introduced there, connected to the police database (ANPR - Automatic Number Plate Recording), which is able to automatically register all license plates of cars entering the City, recognize suspicious numbers within 4 seconds and give a return signal to checkpoints. The anti-terrorist barriers in front of the historic Palace of Westminster are growing. Structures staffed by the police with ready-to-fire rifles are already making the impression of a curious, futuristic artistic installation. It is about preventing the attack with the help of a car trap. Al Qaeda has once tried to assassinate the airport in Glasgow. Fortunately, without success.

In 2014, 30,000 police cameras operated in central London, including many connected to the ANPR system, causing London to become the city with the highest saturation of these devices; a statistical Londoner is photographed every day by about 300 cameras (Rybarczyk, 2014 It is estimated that over 4 million cameras have been installed in the British islands (Sergei, 2010). Each CCTV now includes two high-resolution FCB series cameras from Sony. Images from cameras are sent to the Metropolitan Police data center in New Scotland Yard. These are both color images and infrared images, which the police analyze using the NDI-RS Talon ANPR software recognizing license plates. The data received is automatically compared with the databases of other police, tax and customs offices, the Vehicle Registration Agency and the British Border Guard to detect potential threats, as well as stolen, uninsured or untaxed vehicles. In Warsaw, according to data from the Warsaw Monitoring Systems Department, there are 419 cameras, and images of them go, among others to a special department at the Warsaw Metropolitan Police Headquarters and are also regularly viewed by Warsaw Monitoring Systems Department operators, who report about 10,000 incidents to the police every year. Warsaw cameras are observed on a regular basis, in contrast to British cameras, which are observed at random, and the records are checked only when a crime is committed in the field of observation (Inwigilacja - Oni cię widzą ...). 
Adapting security to threats on a global scale seems to be absurd - it is difficult to talk about public space, access to which is blocked by metal detector gates combined with the need to undergo a personal control. In the months leading up to the Olympic Games in London (2012), the British government, armed forces and Metropolitan Police have prepared for the largest security operation since World War II. In August 2014 in East London, the police detained a "lone wolf" terrorist who was close to a terrorist operation - in his backpack a hammer and cleaver wrapped in an Islamic flag were found - primitive tools, but capable of sowing terror in a large metropolis crowd. Mobile phones are enough for such terrorists. Attacks using the latest technologies are unstoppable. Technologies are improved, and it is impossible to constantly monitor the flow of data. Spies communicate very often from outside the country, and monitoring the network is often treated as an attack on the personal freedom of citizens (Brytyjskie służby ...).

The problem exists and does not apply only to large agglomerations. However, the threat of terrorism cannot explain the mistakes made in many public spaces. More and more often for many the security guarantee is the ease of observation of suspects, and in the event of an attack - detection of the perpetrator. Those responsible for monitoring systems emphasize that the process is under control. Many opponents of this approach to the problem emphasizes, however, that monitoring is extremely dangerous, because technology allows a lot. The British government program "e-borders", which aims to identify people suspected of terrorism during border control, still does not work as it should. The latest report by border and immigration inspector John Vine shows that its implementation only minimally improved security and slightly increased the number of terrorists detained. Creation and implementation of the "e-borders" project consumed 10 years of specialists' work and cost over 500 million pounds. According to its originators, its introduction was to enable the identification of people who could threaten the security, for example, suspected terrorists or other criminals, who were previously deported. A recent check carried out after the introduction of "e-borders" has shown that the program does not work as it should: it has a small impact on the number of suspects detained, part of its monitoring systems are not working and 
there are far too few participating airlines (Projekt ochronny kosztował...). However, some projects seem to be effective. In 2014, a facial recognition system developed by the Californian company 3 VR was tested in a London metro under natural conditions. In a fast-moving crowd, a computer program was able to identify 9 out of 10 people. The new threats to privacy are flying cameras - observation drones. The American army introduced them for use, but the drones are increasingly used by police and special services. Drones are remotely controlled flying devices - small planes or multi-rotor helicopters equipped with the camera and video transmission equipment. Invisible in the sky, the drone can track the selected person for hours, controlled by an operator sitting comfortably in an office chair. Instead of sending agents who risk losing a figurehead or being recognized by an enemy, the drone flies in the air above the head of the tracked person and records all the images. The consequence of an attack on the monitoring system may cause situations that will be beyond any control. Such an attack may result in a Hollywood scenario, in which cybercriminals cheat policemen, sending them images of an alleged accident requiring urgent intervention. When the law enforcement officers were busy organizing the action in one place, the criminals had more freedom to act somewhere else (Systemy kamer miejskiego...).

\section{CONCLUSION}

Poles migrating to Great Britain can see new conditions of their security. They perceive this phenomenon through the existence of a real threat. However, to a much greater extent than in the country of origin, they can feel safe through the existence of a threat. It is threats and their limitation that constitute an important aspect of security. As a result, despite knowing about terrorism or manifestations of social or cultural phobias, Poles emigrate to Great Britain. Creating security in its manifestations is transferred for them from the sphere of theory to practice. Although in the open public space, on city streets, parks and squares, there are personal dangers connected with the perversions of street poverty, drug addiction 
and prostitution, acts of hooliganism and criminal offenses, as well as social threats - attacks and assaults caused by frustrated and aggressive groups or individuals, Poles feel safe. Public space is designed for safe activities. Often, the brightness, clean and well-maintained spaces are a deterrent. Authorities at the state level, local governments rely on network cameras they use to monitor densely populated urban areas. There is a real structure of the security environment in the form of means and methods aimed, for example, limiting vehicular traffic, locks protecting passers-by, monitored means of public transport. Technological extension of creating a security environment leads to a sense of greater security. Poles living in Great Britain see these security measures in contrast to the environment of their country of origin. Residents subjected to a number of CCTV projects experience uninterrupted tracking and their actions through a multi-level structure based on CCTV, video monitoring are recorded (CCTV increases ...). As a result, Poles in the UK may feel much safer in the public space.

\section{BIBLIOGRAPHY:}

Bankowicz, M. (1999). Fenomen demokracji. Kraków: Wyd. PiT.

Bielecki, J. (2016a). Książe Jan Żyliński: Bez Farage’a nie byłoby Brexitu. Downloaded from: www.rp.pl/Brexit/312079892-Ksiaze-Jan-Zylinski-Bez-Faragea-nie-bylobyBrexitu.html\#ap-1.

Bielecki, J. (2016b). On average, every ten minutes the police are informed of a crime with a racial or ethnic undertone. There have been an increasing number of unreported crimes. Downloaded from: https://polska.pl/politics/foreign-affairs/great-britainpoles-targeted/

Brytyjskie stużby specjalne ostrzegają: ISIS planuje masakrę w UK. Downloaded from: http://www.polishexpress.co.uk/brytyjskie-sluzby-specjalne-ostrzegaja-isis-planujemasakre-w-uk1.

Castells, M. (2009). Społeczeństwo sieci, Warszawa: Wydawnictwo Naukowe PWN.

CCTV increases people's sense of anxiety, Downloaded from: www.theguardian.com/ society/2012/oct/30/cctv-increases-peoples-sense-anxiety.

Daily Express: Kwiat bandyctwa? Downloaded from: http://www.polishexpress.co.uk/ daliy-express-kwiat-bandyctwa. 
Donohue, B. Systemy kamer miejskiego monitoringu sa dziurawe. Downloaded from: https://plblog.kaspersky.com/systemy-kamer-miejskiego-monitoringu-sa-dziurawe/3047/.

Giddens, A., Scott Lash, S., Beck. U. (2009). Modernizacja refleksyjna. Warszawa: Wydawnictwo Naukowe PWN.

Gierszewski. J. (2013). Bezpieczeństwo społeczne. Studium z zakresu teorii bezpieczeństwa narodowego. Warszawa: Difin.

Inwigilacja - Oni cię widza, kamery sa wszędzie. Downloaded from: http://techtrendy. pl/title,Inwigilacja-Oni-cie-widza-kamery-sa-wszedzie,wid,14792707,wiadomosc. html?ticaid=515ddc.

Jastrzębski, B. (1999). Podstawowe zasady demokratycznego państwa prawa i administracji publicznej. Płock: Wydawnictwo Naukowe Novum.

Kolejny rasistowski incydent. Nie powinieneś siedzieć w tym pociagu, jeśli nie mówisz $w$ języku angielskim. Downloaded from:, http://www.polishexpress.co.uk/kolejnyrasistowski-incydent-nie-powinienes-siedziec-w-tym-pociagu-jesli-nie-mowisz-wjezyku-angielskim.

Kuźniar, R. (2005), Porzadek międzynarodowy u progu XXI wieku. Warszawa: Wydawnictwo Uniwersytetu Warszawskiego.

Kwiatkowski, S., Kwiatkowska-Drożdż. A. (2005). O bezpieczeństwie obywateli i zarządzaniu kryzysowym. Tyczyn: Wyższa Szk. Społeczno-Gospodarcza.

Misiuk, A. (2011). Administracja porządku i bezpieczeństwa publicznego. Zagadnienia prawno- ustrojowe. Warszawa: Oficyna Wydawnicza Łośgraf.

Mochnaczewski, P., Bolesta, A. (2007). Nowa europejska polityka imigracyjna i azylowa: w kierunku twierdzy „Europa”? In: P. Mochnaczewski, A. Bolesta (eds.). Polityka migracyjna, w poszukiwaniu nowych standardów ochrony i pomocy. Warszawa: Wyższa Szkoła Zarządzania i Prawa.

Orłowska, R. (2013). Uwarunkowania i skutki rozwoju migracji ekonomicznej w Unii europejskiej w świetle wybranych teorii migracji międzynarodowych. Gdańsk: Wydawnictwo Uniwersytetu Gdańskiego.

Piotrowski, M. Rząd odcina imigrantów od zasiłków. Downloaded from: http://rezydentuk.co.uk/rzad-odcina-imigrantow-zasilkow.

Poland flags burned on bonfires across Belfast on 11 July. BBC News. 19.07.2012. Downloaded from: http://www.bbc.com/news/uk-northern-ireland-18895671.

Poles are biggest non-UK born population: Indians overtaken as EU nationals top 3million, Downloaded from: www.express.co.uk/news/uk/703849/poles-poland-migrants-livein-uk

Projekt ochronny kosztował miliony funtów. Wciąż nie działa. Downloaded from: http:// www.polishexpress.co.uk/projekt-ochronny-kosztowal-miliony-funtow-wciaz-niedziala. 
Rybarczyk, M. (2014). Londyn czeka na zamach, Newsweek Polska, 25.11, Downloaded from: http://swiat.newsweek.pl/zagrozenie-terrorystyczne-w-londynie-i-na-wyspach-brytyjskich-newsweek,artykuly,352437,1.html.

Scheffer, P. (2010). Druga ojczyzna. Imigranci w społeczeństwie otwartym, przeł. Ewa Jusewicz-Kalter. Wołowiec: Wydawnictwo Czarne.

Setki islamistów z ISIS żyje tuż obok nas! Brytyjskie stużby lekceważą nasze bezpieczeństwo, Downloaded from: http://www.polishexpress.co.uk/setki-islamistow-z-isis-zyje-tuzobok-nas-brytyjskie-sluzby-lekcewaza-nasze-bezpieczenstwo 112 .

Siergiej, P. (2010). Wielki brat na Manhattanie, Wyborcza.pl, 6.01. Downloaded from: http://wyborcza.pl/1,75476,7424790,Wielki_Brat_na_Manhattanie.html

Uniting and Strengthening America by Providing Appropriate Tools Required to Intercept and Obstruct Terrorism Act of 2001; Public Law Pub.L. 107-56. Downloaded from: www.realclearpolitics.com/video/2015/05/20/rand_paul_filibusters_i_will_not_let_ the_patriot_act_the_most_unpatriotic_of_acts_go_unchallenged.html.

Urban. A. (2009). Bezpieczeństwo społeczności lokalnych. Warszawa: Oficyna Wydawnicza Łośgraf.

Wojtaszczyk. K.A. (2000). Kompendium wiedzy o państwie wspótczesnym. Warszawa: Wydawnictwo Liber.

W tym mieście Brytyjczycy nienawidza Polaków. Dlaczego? Downloaded from: http:// www.polishexpress.co.uk/w-tym-miescie-brytyjczycy-nienawidza-polakowdlaczego 13.

Waever, O. (1995). Identity, Integration and Security: Solving the Sovereignty Puzzle in EU Studies. Journal of International Affairs, 48 (2).

Zagrożenie terroryzmem po zamachach $w$ Brukseli, Komunikat z badań NR 65/2016 Warszawa, kwiecień 2016. Downloaded from: www.cbos.pl/SPISKOM. POL/2016/K_065_16.PDF.

Zamojski, J. (2006). Migracje - dzieje i aktualia. Refleksje. In: A. Furdal, W. Wysoczański (eds.). Migracje: dzieje, typologia, definicje. Wrocław: Wydawnictwo Uniwersytetu Wrocławskiego.

Zuchowicz, K. To przez nich chcemy Brexitu. Brytyjczycy pokazuja Boston - największe skupisko Polaków $i$ innych imigrantów. Downloaded from: http://natemat. pl/183089,to-przez-nich-chcemy-brexitu-brytyjczycy-pokazuja-na-boston-najwieksze-skupisko-polakow-i-innych-imigrantow. 